\title{
Optimasi Sosial-Ekonomi pada Pemanfaatan PLTS PV untuk Energi Berkelanjutan di Indonesia
}

\author{
Jon Marjuni Kadang, Jaka Windarta \\ Magister Energi, Sekolah Pascasarjana, Universitas Diponegoro; \\ Email :jonmrkadang@students.undip.ac.id (J.M.K), jakawindarta@lecturer.undip.ac.id (J.W.);
}

\begin{abstract}
Abstrak : Teknologi Photovoltaic (PV) memberikan peluang menjanjikan pada energi terbarukan dan berkelanjutan dimana bersumber dari matahari yang tidak terbatas dibandingkan sumber energi fosil. Letak Indonesia sepanjang jalur khatulistiwa memberikan sumber energi matahari yang besar dengan intensitas rata-rata hingga 2.000 jam per tahun. Total intensitas penyinaran per hari dapat mencapai 4500 Watt hour $/ \mathrm{m}^{2}$. Namun, pengembangan dan pemanfaatan PLTS PV belum optimal dan mengalami berbagai kendala. Pada kajian ini dibahas tentang PLTS PV terkait potensi pengembangan PLTS PV sebagai energi terbarukan serta optimasi pemanfaatan PLTS PV pada aspek sosial-ekonomi. Dan juga dilakukan evaluasi kendala serta mitigasi solusi yang dibutuhkan untuk peningkatan pemanfaatan PLTS PV terutama keekonomian PLTS PV yang mendukung upaya peningkatan rasio elektrifikasi khususnya pada daerah 3T (Terdepan, Terpencil, dan Tertinggal) di Indonesia. Dari kajian diperoleh bahwa biaya investasi dan LCOE PLTS PV mengalami tren penurunan sehingga pengembangan PLTS PV menjadi semakin menarik secara keekonomian dan menguntungkan secara sosial pada daerah 3T sebagai solusi energi berkelanjutan di Indonesia.
\end{abstract}

Kata Kunci : Photovoltaic, Energi, Sosial-Ekonomi

\section{Pendahuluan}

Kondisi kelistrikan Indonesia terutama di pulau-pulau terluar, dekat perbatasan sebagian besar masih PLTD dimana Harga HSD dan Biaya Transportasinya sangat mahal, sehingga Biaya Pokok Produksi (BPP) di daerah tersebut rata-rata masih $>$ Rp 3.000/kWh. Indonesia adalah negara yang terletak di khatulistiwa yang memiliki sumber energi surya yang sangat melimpah. Intensitas radiasi matahari rata-rata di Indonesia mencapai rata-rata $4.8 \mathrm{kWh} / \mathrm{m}^{2}$ per hari. PLN mengembangkan program PLTS PV di berbagai lokasi/pulau terutama di wilayah terluar maupun yang terisolasi (daerah 3T) untuk mempercepat rasio elektrifikasi. Dimana dikembangkan PLTS Terpusat/Komunal dengan mode Hybrid. Seluruh PLTS PV ini akan dibangun dengan konfigurasi sebagai berikut:

1) Pengembangan PLTS oleh PLN:

a. PLTS Off Grid (kapasitas 10 s.d $100 \mathrm{~kW}$ )

- PV Stand Alone System, terkoneksi ke LV (Low Voltage) Feeder 230V/400V atau MV (Medium Voltage) line 20 kV, PV dan storage bank/battery) 
b. PLTS On Grid (kapasitas 100 s.d 1000 kW)

- Sistem hybrid dengan PLTD atau pembangkit lain (PV dan baterai), terkoneksi ke MV baru atau eksisting.

- Sistem on grid yang terhubung dengan MV line eksisting tanpa menggunakan baterai

2) Pengembangan PLTS oleh IPP

Sistem On Grid (kapasitas 1 s.d 10 MW) yang terkoneksi ke MV line eksisting tanpa menggunakan baterai.

Kondisi geografis Indonesia terdiri dari beribu-ribu pulau dengan penyebaran penduduk tidak merata merupakan kendala utama menambah jaringan distribusi pembangkit listrik ke setiap pelosok. PLTS PV yang dibangun di daerah yang terisolasi dari jaringan distribusi telah memberikan perkembangan yang besar pada masyarakat yang sebelumnya belum mengenal listrik. Listrik dari PLTS PV yang ramah lingkungan telah memungkinkan dibangunnya fasilitas kesehatan dan pendidikan yang lebih memadai.

Pembangunan PLTS PV $600 \mathrm{kWp}$ akan mampu mengurangi BBM setara 800 liter/hari atau mencapai 2,5 Milyar/tahun (jika operasi optimal). Losses bisa dari desain dan enjiniring, karakteristik peralatan, pemeliharaan yang kurang optimal, pengoperasian yang kurang optimal, dan pengaruh eksternal.

Pembangunan PLTS PV dilaksanaan secara selektif karena investasinya besar. dan diharapkan mampu bertahan untuk mendukung pengurangan BBM PLTD hingga 20 tahun. Dengan pengelolaan yang kurang optimal, bukan hanya performance ratio dari PLTS yang tidak terpenuhi sehingga BBM masih banyak digunakan, tapi modal investasi yang besar tidak akan mencapai pengembaliannya.

Melalui kajian ini dilakukan pembahasan PLTS PV terkait potensi dan pengembangan PLTS PV sebagai energi terbarukan serta optimasi pemanfaatan PLTS PV pada aspek sosial-ekonomi. Dan juga dilakukan evaluasi kendala serta mitigasi solusi yang dibutuhkan untuk peningkatan pemanfaatan PLTS PV di Indonesia terutama keekonomian PLTS PV untuk mendukung upaya peningkatan rasio elektrifikasi di Indonesia khususnya pada daerah 3T (Terdepan, Terpencil, dan Tertinggal).

\section{Dasar Teori}

Energi matahari hanya $69 \%$ yang diterima permukaan bumi. Pada permukaan bumi, energi matahari sebesar $3 \times 1.024$ joule/tahun atau $2 \times 1.017 \mathrm{~W}$ (setara 10.000 kali kebutuhan energi dunia). Memanfaatkan $0,1 \%$ permukaan bumi dengan sel surya (efisiensi $10 \%$ ) sudah dapat mencukupi kebutuhan energi dunia (Hasbullah, 2017).

Indonesia terletak di sepanjang jalur khatulistiwa $\left(11^{\circ} \mathrm{LU}\right.$ dan $\left.6^{\circ} \mathrm{LS}\right)$ memiliki intensitas sinar matahari yang cukup stabil sepanjang tahun dan potensinya besar untuk EBT (LIPI, Buku Indonesia 2005-2025, 2012).

Pemanfaatan energi terbarukan dari energi matahari melalui Pembangkit Listrik Tenaga Surya (PLTS) PV. PhotovoltaicCell/Sel Surya terdiri atas dua sambungan pada area dua lapisan tipis semikonduktor (jenis $\mathrm{p}$ dan n). PLTS PV adalah sistem pembangkitan listrik berdasarkan hasil konversi energi matahari melalui media fotovoltaik (PV). PLTS PV memanfaatkan teknologi modern serta ramah lingkungan, namun biaya investasi awal yang menjadi kendala utama.

KEN (Kebijakan Energi Nasional) tentang bauran EBT sebesar 23\% terhadap total energi primer pada 2025. Pada 2050 bauran EBT ditargetkan sebesar 31\%. Rencana implementasi KEN tertuang dalam Peraturan Presiden No 22/2017 tentang RUEN. 


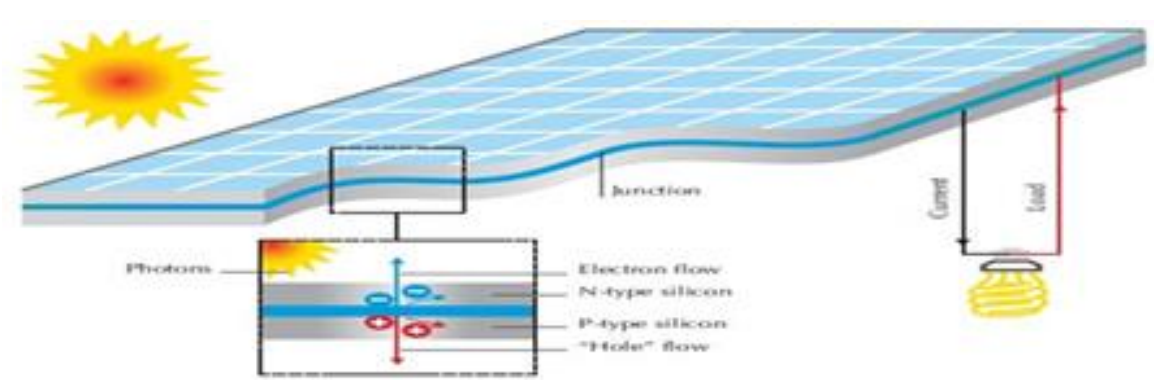

Gambar 1. Ilustrasi Photovoltaic Cell

Pengembangan PLTS PV diproyeksikan sebesar 6,5GW pada 2025 dan 45GW pada 2050, dapat dilihat pada Tabel 1.

Tabel 1.

Pengembangan PLTS PV dalam Bauran EBT s.d Tahun 2050

\begin{tabular}{lccccccc}
\hline \multirow{2}{*}{ Energi } & \multicolumn{7}{c}{ Kapasitas (MW) } \\
\cline { 2 - 8 } & 2018 & 2019 & 2020 & 2025 & 2030 & 2040 & 2050 \\
\hline Panas Bumi & $2.133,5$ & $2.493,5$ & $3.109,5$ & $7.241,5$ & $9.300,0$ & $13.423,0$ & $17.546,0$ \\
Air & $5.103,7$ & $5.468,2$ & $5.615,2$ & $17.986,7$ & $21.989,4$ & $29.994,7$ & $38.000,0$ \\
Minihidro dan Mikrohidro & 520,0 & 750,0 & $1.000,0$ & $3.000,0$ & $3.800,0$ & $5.400,0$ & $7.000,0$ \\
Bioenergi & $2.030,0$ & $2.200,0$ & $2.500,0$ & $5.500,0$ & $9.600,0$ & $17.800,0$ & $26.000,0$ \\
Surya & 375,0 & 550,0 & 900,0 & $6.500,0$ & $14.200,0$ & $29.600,0$ & $45.000,0$ \\
Angin & 203,9 & 398,9 & 600,0 & $1.800,0$ & $7.040,0$ & $17.520,0$ & $28.000,0$ \\
EBT Lainnya & $1.675,4$ & $2.059,2$ & $2.433,0$ & $3.125,0$ & $3.722,4$ & $4.911,1$ & $6.100,0$ \\
\hline \multicolumn{1}{c}{ Total } & $12.041,5$ & $13.919,8$ & $16.157,7$ & $45.153,2$ & $69.651,8$ & $118.648,8$ & $167.646,0$ \\
\hline
\end{tabular}

Tabel 2.

Kapasitas Terpasang PLT Berbasis Energi Terbarukan Tahun 2014 - 2019 (lihat PLTS)

\begin{tabular}{lcccccc}
\hline \multirow{2}{*}{ Jenis Pembangkit } & \multicolumn{5}{c}{ Kapasitas (MW) } \\
\cline { 2 - 7 } & 2014 & 2015 & 2016 & 2017 & 2018 & 2019 \\
\hline PLTA & $5.048,59$ & $5.068,59$ & $5.343,59$ & $5.343,59$ & $5.399,59$ & $5.558,52$ \\
PLTB & 1,46 & 1,46 & 1,46 & 1,46 & 143,51 & 154,31 \\
PLTBg & 28,80 & 54,72 & 64,16 & 100,62 & 108,62 & 110,62 \\
PLTBm & $1.359,87$ & $1.671,29$ & $1.703,29$ & $1.740,54$ & $1.758,54$ & $1.758,54$ \\
PLTBn & 0,00 & 0,00 & 0,00 & 0,00 & 0,00 & 5,00 \\
PLTM & 111,26 & 148,71 & 211,40 & 240,55 & 267,79 & 311,14 \\
PLTMH & 76,95 & 90,15 & 95,87 & 103,76 & 104,76 & 106,36 \\
PLTP & $1.403,30$ & $1.438,30$ & $1.533,30$ & $1.808,30$ & $1.948,30$ & $2.130,70$ \\
PLTS & 22,74 & 33,36 & 43,12 & 50,90 & 60,19 & 126,24 \\
PLTS Atap & 0,00 & 0,00 & 0,00 & 0,00 & 0,00 & 19,57 \\
PLTS Hybrid & 0,00 & 3,50 & 3,50 & 3,50 & 3,50 & 3,50 \\
PLTS Hybrid (Surya - Angin) & 0,08 & 0,08 & 0,08 & 0,08 & 0,08 & 0,08 \\
PLTSa & 14,00 & 15,65 & 15,65 & 15,65 & 15,65 & 15,65 \\
\hline \multicolumn{1}{c}{ Total } & $8.067,05$ & $8.525,81$ & $9.015,42$ & $9.408,95$ & $9.810,53$ & $10.300,23$ \\
\hline
\end{tabular}


Selanjutnya, dalam 5 tahun terakhir capaian bauran EBT masih berada jauh di bawah target tahunan yang diproyeksikan, walaupun terjadi peningkatan pemanfaatan EBT sejak tahun 2018. Pertumbuhan pasokan energi terbarukan menunjukkan perkembangan yang positif karena mampu tumbuh mencapai $26 \%$ per tahun atau mencapai 20,04 MTOE pada tahun 2019, namun pengembangan pembangkit listrik EBT baru mencapai 10,2 GW atau di bawah target RUEN sebesar 13,9 GW. Saat pembangkit listrik EBT masih didominasi oleh PLTA, PLTP, dan PLTBM (Tabel 2). Gambaran ini menunjukkan bahwa pengembangan sumber EBT masih kurang mendapatkan perhatian dalam pengembangan kapasitas lebih lanjut khususnya pada PLTS PV.

Selain itu, percepatan elektrifikasi EBT untuk pembangkit listrik juga menghadapi masalah khususnya untuk pembangkit listrik dengan skala kecil, hal ini terjadi akibat letak pembangkit listrik skala kecil umumnya berada di lokasi yang terpencil dan jauh dari infrastuk tur pendukung jaringan listrik baik transmisi ataupun distribusi, sehingga untuk menyalurkan produksi tenaga listrik dari pembangkit melalui jaringan listrik membutuhkan investasi besar yang akan dibebankan kepada pengembang. Intermitensi juga menjadi salah satu kendala dalam pengembangan pembangkit listrik EBT skala kecil, mengingat sifat intermitensi tersebut dapat menimbulkan gangguan terkait kestabilan sistem ketenagalistrikan dimana pembangkit tersambung.

\section{HASIL DAN PEMBAHASAN}

\subsection{Photovoltaic Cell (PV) sebagai PLTS}

\subsubsection{Komponen Utama PLTS PV}

1) PV modul merupakan sebuah semikonduktor dengan permukaan luas, terdiri dari rangkaian dioda tipe $\mathrm{n}$ dan $\mathrm{p}$, yang mengkonversi energi matahari menjadi listrik.

2) Bi-Directional Inverter adalah komponen elektronik yang merubah tegangan DC menjadi AC dan juga sebaliknya dari sistem AC ke DC. Atau Inverter biasa hanya mampu mengkonversi dari DC menjadi AC, dengan adanya inverter maka PLTS dapat beroperasi parallel dengan generator lain.

3) Charge Controller \& Baterai, Charge Controller mengatur pengisian energi DC ke Baterai untuk menyimpan energi listrik.

\subsubsection{Konfigurasi Utama PLTS PV}

Konfigurasi utama PLTS PV terdiri dari sistem berdiri sendiri (Stand Alone System), dan sistem yang dihubungkan ke utilitas/jaringan lain:

1) Sistem Berdiri Sendiri (Stand Alone System)

Sistem yang memproduksi daya listrik dan berdiri sendiri serta direncanakan dan dibangun untuk tidak dihubungkan ke utilitas/jaringan listrik eksisting. Sistem berdiri sendiri ( sistem Off-Grid) merupakan sistem PLTS Komunal yang terisolasi dari jaringan/sistem luar. Sistem ini dibangun bila di dalam suatu kawasan tidak terdapat jaringan listrik, atau jauh dari sumber jaringan.

Kriteria pembangunan PLTS Sistem berdiri sendiri/Off grid sebagai berikut:

a. Daerah yang belum berlistrik dan/atau berada pada wilayah perbatasan negara, dan/atau ibukota pemerintahan;

b. Daerah tersebut terbatas memiliki potensi energi primer dari EBT lainnya;

c. Kondisi geografis dengan mempertimbangkan: 
- Jarak lokasi dari jaringan PLN adalah lebih dari $5 \mathrm{~km}$ atau apabila perluasan jaringan TM/TR ke lokasi tidak memungkinkan atau biaya perluasan jaringan ke lokasi lebih mahal dari biaya pengembangan PLTS Terpusat (Komunal);

- Jumlah calon pelanggan minimal 50 dengan panjang jaringan yang masih memenuhi persyaratan teknis;

d. Rencana sistem beroperasi minimal 12 (dua belas) jam perhari.

2) Sistem Terhubung ke Jaringan (Utility Connected System)

Sistem yang memproduksi daya listrik yang terhubung ke utilitas/jaringan listrik yang ada. Sistem ini dapat dikelompokkan menjadi:

a. PLTS Sistem On Grid

Sistem PLTS yang dihubungkan ke utilitas/jaringan yang sudah ada. PLTS sistem on grid dibangun untuk mengurangi/membatasi pemakaian bahan bakar minyak oleh PLTD yang ada. PLTS On Grid tidak dilengkapi dengan baterai sebagai penyimpan cadangan energi. Kriteria pembangunan PLTS Sistem On Grid, yaitu:

- Sistem eksisting telah beroperasi 24 jam perhari atau beroperasi siang hari;

- Dengan maksud mengurangi/membatasi pemakaian bahan bakar minyak;

- Penyambungan sistem PLTS ke sistem eksisting tidak mengganggu operasional sistem eksisting.

b. PLTS Sistem Hybrid

Sistem PLTS yang dihubungkan ke utilitas/jaringan yang sudah ada, dan dioperasikan dengan pembangkit yang sudah ada (PLTD, PLTM, PLTB, dll) dengan pengaturan dan pembagian waktu operasi masing-masing pembangkit secara optimal. PLTS Hybrid dilengkapi battery storage. Kriteria pembangunan PLTS Sistem Hybrid sebagai berikut:.

- Menambah jam pelayanan sistem eksisting terutama periode siang hari;

- Dengan maksud mengurangi jam operasi PLTD eksisting;

- Sistem dilengkapi batere dengan kapasitas sesuai pola operasi.

\subsection{Perbandingan Aspek Sosial-Ekonomi PLTS PV dengan Pembangkit Konvensional}

Untuk dapat membandingkan kelebihan dan kekurangan Pembangkit Konvensional dan PLTS PV sebagai Energi Terbarukan maka dapat dilakukan kajian sesuai tinjauan sosial serta ekonomi.

\subsubsection{Aspek Sosial PLTS PV}

Bila ditinjau dari aspek sosial sebuah pembangkit listrik memiliki empat kategori dasar yaitu:

1) Biaya sosial, diukur dengan besar kecilnya polusi yang dihasilkan pembangkit.

2) Biaya internal, O\&M dan investasi.

3) Manfaat sosial, diukur dengan standar kehidupan dengan lingkungan yang baik.

4) Manfaat internal, revenue yang diperoleh dari penjualan listrik.

Bila ditinjau dari keempat kategori tersebut Pembangkit listrik jenis konvensional memiliki biaya internal yang rendah namun biaya sosialnya sangat tinggi, pembangkit konvensional menghasilkan efek samping sebagai berikut :

1) Emisi karbon dioksida $\left(\mathrm{CO}_{2}\right)$ dan Methane $\left(\mathrm{CH}_{4}\right)$ yang berimplikasi pada Pemanasan Global.

2) Polusi udara, air dan tanah akan menurunkan kualitas hasil pertanian dan kesehatan. 

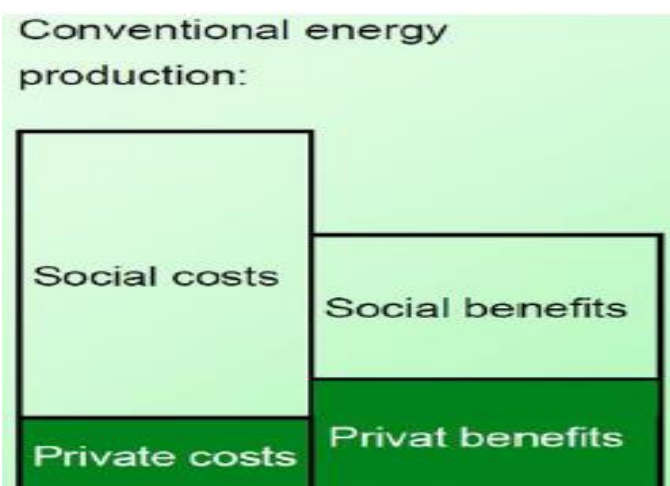

\section{Renewable energy}

production:

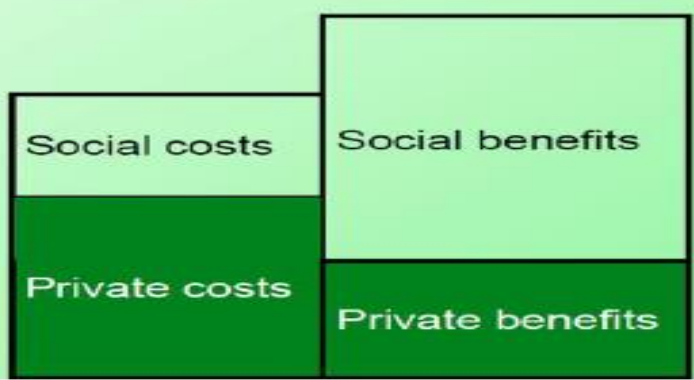

Gambar 2. Perbandingan Struktur Biaya dan Manafaat antara Produksi Energi Konvensional dan Terbarukan (Sumber : Wiesmeth, Golde)

Sebaliknya dari perspektif bisnis PLTS PV bukan termasuk energi alternatif yang murah, namun manfaat sosialnya tinggi dan biaya sosialnya sangat rendah (Wiesmeth, 2014), sehingga perlu dipertimbangkan hal-hal berikut :

1) Memperbaiki standar kehidupan dengan lingkungan yang bersih dan sehat.

2) Meningkatkan kesejahteraan, meningkatkan wawasan informasi dan pendidikan, menciptakan peluang pekerjaan melalui supplai listrik pada daerah terpencil/kepulauan yang tidak terjangkau grid.

3) Penghematan investasi transmisi listrik melalui desentralisasi dengan PLTS PV.

4) Penghematan biaya transportasi dan operasi \& pemeliharaan dari PLTD daerah terpencil/kepulauan yang tidak terjangkau grid.

Pada negara negara maju seperti Jerman, Jepang dan Amerika terdapat kebijakan nasional sebagai solusi atas permasalahan tersebut, yaitu:

1) Program Power Purchasing

2) Diskon pajak untuk pembangkit terbarukan

3) Subsidi khusus

4) Pajak emisi bagi pembangkit konvensional.

Dengan adanya penyesuaian kebijakan pada Energi Terbarukan dan pengetatan terhadap pembangkit konvensional yang menghasilkan polusi lingkungan maka diharapkan pemanfaatan Energi Terbarukan utamanya PLTS PV semakin menarik dan meningkat.

\subsubsection{Aspek Ekonomi PLTS PV}

Dari sisi keekonomian, antara Pembangkit Konvensional dengan Energi Terbarukan dapat dianalisa beberapa aspek, diantaranya adalah tinjauan Biaya Konstruksi dari berbagai jenis Pembangkit.

Tabel 3 menginformasikan bahwa biaya konstruksi pembangkit PLTS PV relatif mahal bila dibandingkan pembangkit lain terlebih lagi dengan Capacity Factor yang rendah, sehingga bila dikaji dari biaya konstruksi, investasi pada PLTS PV kurang menarik. 
Tabel 3.

Perbandingan Biaya Konstruksi dari Berbagai Jenis Pembangkit

\begin{tabular}{|c|c|c|c|c|c|}
\hline Technology & \multicolumn{2}{|c|}{$\begin{array}{c}\text { Overnight } \\
\text { Construction } \\
\text { Cost }(\mathrm{US} \$ / \mathrm{kW})\end{array}$} & \multirow{2}{*}{$\begin{array}{c}\text { Plant } \\
\text { Economic } \\
\text { Life (Years) } \\
25\end{array}$} & $\begin{array}{c}\text { Capacity } \\
\text { Factor } \\
(\%) \\
\end{array}$ & Source \\
\hline \multirow[t]{2}{*}{ Solar PV } & Min & 2878 & & 21 & NEA/IEA \\
\hline & Max & 7381 & 25 & 20 & NEA/IEA \\
\hline \multirow[t]{2}{*}{ Solar CSP } & Min & 4347 & 25 & 34 & NEA/IEA \\
\hline & Max & 5800 & 20 & 26 & Lazard \\
\hline \multirow[t]{2}{*}{ Wind } & Min & 1223 & 25 & 27 & NEA/IEA \\
\hline & Max & 3716 & 25 & 23 & NEA/IEA \\
\hline \multirow[t]{2}{*}{ Gas CC } & Min & 538 & 30 & 85 & NEA/IEA \\
\hline & Max & 2611 & 30 & 85 & NEA/IEA \\
\hline \multirow[t]{2}{*}{ Gas CT } & Min & 483 & 25 & 85 & NEA/IEA (2005) \\
\hline & Max & 1575 & 20 & 10 & Lazard \\
\hline \multirow[t]{2}{*}{ Hydro } & Min & 757 & 80 & 34 & NEA/IEA \\
\hline & Max & 3452 & 20 & 50 & CPUC \\
\hline \multirow[t]{2}{*}{ IGCC w CSS } & Min & 3569 & 40 & 85 & NEA/IEA \\
\hline & Max & 6268 & 40 & 85 & NEA/IEA \\
\hline \multirow[t]{2}{*}{ Supercritical } & Min & 1958 & 40 & 85 & NEA/IEA \\
\hline & Max & 2539 & 40 & 85 & NEA/IEA \\
\hline \multirow[t]{2}{*}{ Nuclear } & Min & 3389 & 60 & 20 & EIA \\
\hline & Max & 8375 & 20 & 90 & Lazard \\
\hline
\end{tabular}

Bila dievaluasi secara keseluruhan dengan mempertimbangkan seluruh komponen biaya dengan metode Levelized Cost of Electricity Generation dengan formula sebagai berikut :

$$
\begin{gathered}
\mathrm{CRF}=\frac{\mathrm{r} \times(1+\mathrm{r})^{\mathrm{T}}}{(1+\mathrm{r})^{\mathrm{T}}-1} \\
\mathrm{LCOE}=\frac{\mathrm{OC}}{\mathrm{CF} \times 8.760} \times \mathrm{CRF}+\mathrm{OMC}+\mathrm{FC}
\end{gathered}
$$

Dimana :

OC : Biaya Investasi Awal

OMC : Biaya Operasi dan Pemeliharaan

FC : Biaya Bahan Bakar

Maka akan diperoleh perbandingan biaya pembangkit seperti pada Gambar 3.

Dari Gambar 3 dapat dievaluasi secara keseluruhan dengan metode Levelized Cost dengan asumsi PLTS PV pada level minimum dan pembangkit lain pada level maksimum dalam periode tertentu maka PLTS PV masih yang paling mahal dibanding Pembangkit lain (Hydropowwer, Bioenergy, Geothermal). Biaya produksi PLTS PV dari masa ke masa mengalami penurunan karena perkembangan teknologi material pada thin film penyusun PV yang semakin efektif, dan diproduksi oleh banyak produsen yang umumnya di negara maju sehingga tercipta persaingan harga yang cukup ketat, terlebih lagi produksi PV secara masal mengakibatkan harga yang kompetitif cenderung 
semakin terjangkau dapat dilihat dari kurva di atas. Melihat kecenderungan kurva di atas, terdapat kemungkinan bahwa nantinya pemanfaatan Energi Terbarukan utamanya teknologi Solar PV akan semakin menarik dengan jumlah output yang terus meningkat.
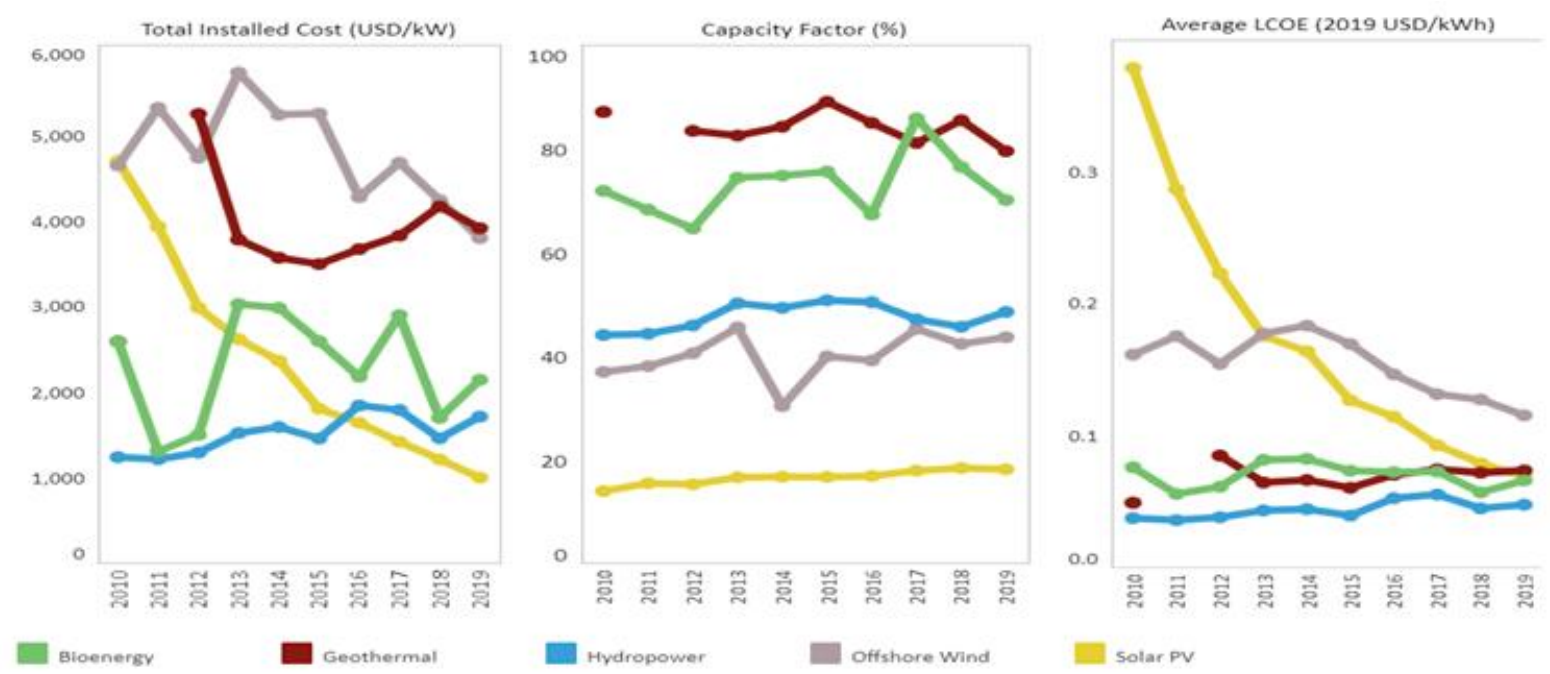

Gambar 3. Kurva Penurunan Global Weighted Average Total Installed Cost, Capacity Factors, dan Average LCOE Solar PV 2010-2019 (USD/kWh)

(Sumber: https://www.irena.org/publications/2020/Jun/Renewable-Power-Costs-in-2019)

\subsection{Kendala PLTS PV \& Mitigasi}

\subsubsection{Kendala PLTS PV}

Dalam penerapan teknologi PV terdapat beberapa kendala yang dihadapi, yaitu:

1) Tingginya harga investasi menjadikan tidak mudahnya konsistensi pendanaan pada Negara berkembang.

2) Resiko investasi oleh beberapa Institusi perbankan menjadi resiko yang sangat tinggi atas produk yang belum memiliki pengalaman atas life time, panjangnya masa Pay Back Periods (PBP) dan kecilnya Revenue.

3) Biaya BoS tidak mengalami penurunan seiring dengan penurunan harga modul PV.

4) Hambatan pada prosedur untuk interkoneksi, metering dan billing.

5) Minimnya training, perencanaan dan koordinasi engineering dan pemeliharaan.

6) Rendahnya effisiensi PV cell : 4 sampai dengan 12\% (thin film) dan dibawah $22 \%$ (crystalline) dan keterbatasan performance dari Balance Of System (BoS).

Indonesia sebagai negara kepulauan sangat cocok untuk menerapkan PLTS PV karena lokasinya yang menyebar dan tidak terjangkau oleh grid, terlebih lokasinya di sepanjang khatulistiwa yang menjanjikan tersedianya intensitas radiasi matahari sepanjang tahun. Bila kebutuhan listrik daerah kepulauan disuplai oleh PLTD maka akan terjadi pemborosan dari sisi energi primernya dan juga diperlukan biaya transportasi BBM serta biaya operasi dan pemeliharaan yang tinggi, ketidakpastian cuaca juga seringkali menyebabkan suplay BBM terhambat. 


\subsubsection{Mitigasi}

Langkah-langkah mitigasinya adalah sinergi berbagai Stakeholder berupa :

1) Perlu terobosan baru yang bisa membuat Investor mendapatkan keuntungan yang memadai dalam pengembangan PLTS PV. Pada masa transisi saat ini biaya investasi PLTS PV masih cukup tinggi.

2) Mengoptimalkan pemanfaatan PLTS PV (Skala Kecil dan Skala Besar) dengan memperhatikan Prinsip Keekonomian.

- Prinsip Keekonomian tidak hanya mengacu pada faktor harga namun pula mendukung kemajuan dan kegiatan ekonomi daerah, penyerapan angkatan kerja, serta faktor lingkungan,

- Melakukan peningkatan kuatitas dan kualitas survei terhadap potensi energi dari matahari.

- Mengoptimlakan pemanfaatan PLTS PV pada daerah 3T (Terdepan, Terpencil, dan Tertinggal).

- Mewajibkan PEMDA membangun dan mengelola PLTS PV melalui BUMD.

3) Pemerintah diharapkan dapat mendorong pengembangan industri PLTS PV dalam negeri sehingga ke depan biaya investasi dapat menurun seiring dengan pengembangan energi terbarukan yang semakin masif.

4) Insentif Fiskal dalam percepatan pengembangan PLTS PV.

5) Skema Pembiayaan dan Penjaminan Infrastruktur PLTS PV.

6) Pemerintah menugaskan suatu badan usaha khusus EBT untuk peningkatan implementasi EBT khususnya di Kepulauan.

7) Melakukan penyesuian Feed-In-Tariff pembangkit EBT sesuai kebutuhan.

8) Melakukan standarisasi subsidi energi oleh PEMDA pada APBD.

9) Melakukan anggaran pembangunan EBT secara berkelanjutan pada daerah yang terisolasi jangka panjang.

10) Memberikan penugasan kepada lembaga pembiayaan (mis: PERBANKAN) pada proyek EBT.

11) Meningkatkan layanan listrik berbasi EBT di daerah yang sulit akses jaringan/grid.

12) Membangun pembangkit EBT Skala Besar (PLTS PV).

\section{Kesimpulan}

Energi Matahari adalah sumber daya Energi Terbarukan yang sangat berpotensi di Indonesia yang dapat dioptimalkan melalui PLTS PV untuk ketersediaan energi listrik di daerah terpencil dan kepulauan serta dapat mengatasi masalah lingkungan dan solusi jangka panjang untuk energy security.

Biaya investasi dan LCOE PLTS PV mengalami tren penurunan sehingga pengembangan PLTS PV menjadi semakin menarik bagi Investor.

Dibutuhkan peningkatan sinergi berbagai Stakeholder dalam mengembangkan dan meningkatkan pemanfaatan PLTS PV untuk mengatasi kendala pendanaan, investasi awal, dan tingkat risiko tinggi. 


\section{Daftar Pustaka}

A. Sugiyono (2020), Dampak Kebijakan Biaya Pokok Penyediaan Pembangkitan Listrik Terhadap Pengembangan Pembangkit Listrik Berbasis Energi Terbarukan, Prosiding Seminar Nasional Asosiasi Analis Kebijakan, hal. 9-19, AAKI.

BPPT - Outlook Energi Indonesia 2019, Dampak Peningkatan Pemanfaatan Ebt Terhadap Perekonomian Nasional

Buku Bauran Energi 2020, Dewan Energi Nasional (DEN).

Buku Indonesia 2005-2025, Penelitian, Pengembangan dan Penerapan Ilmu Pengetahuan dan Teknologi Bidang Sumber Energi Baru dan Terbarukan untuk Mendukung Keamanan Ketersediaan Energi Tahun 2025.

Ditjen Gatrik, Statistik Ketenagalistrikan 2018, Direktorat Jenderal Ketenagalistrikan, Kementerian ESDM, 2019. PLN Statistik 2018, PT PLN Persero, 2019.

Ditjen Gatrik, Kebijakan Peningkatan Pemanfaatan EBT untuk Pembangkit Tenaga Listrik, Seminar Road to Energy Transition, METI, Jakarta, 12 September 2019.

Govinda R. Timilsina (2011),"A Review of Solar Energy Markets, Economics and Policies", The World Bank Development Research Group Environment and Energy Team.

Hasbullah, "Konversi Energi Surya", (2017) Teknik Elektro FTPK UPI.

Indonesia Energy Outlook 2019, Dewan Energi Nasional (DEN).

Kebijakan Energi Nasional (KEN), Peraturan Pemerintah Reopublik Indonesia No.79 Tahun 2014

Rencana Umum Energi Nasional (RUEN), Peraturan Presiden Republik Indonesia No.22 Tahun 2017

Rencana Umum Ketenagalistrikan Nasional (RUKN) 2019-2038, Kementerian ESDM 2019

Rencana Usaha Penyediaan Tenaga Listrik (RUPTL) PT PLN (Persero) 2019-2028, PT PLN (Persero), Jakarta, 2019.

Sahala M. Lumbanraja, "PLTN dan PLTS sebagai alternatif suplai energi di Indonesia," Prosiding Seminar Nasional Pengembangan Energi Nuklir V, BATAN, 2012.

"Solar Energy Fact Sheet" NC Sustainable Energy Ascociation, (2019) www.energync.org.

Wiesmeth, M Golde (2014), "Social Economic Benefits of Renewable Energy", Technical University Dresden, Germany. 